\title{
PENGARUH PSIKOLOGI REKAYASA TATA RUANG KERJA TERHADAP MOTIVASI KERJA TENAGA KEPENDIDIKAN UNIVERSITAS TEKNOLOGI SUMBAWA
}

\author{
Lana Zakiya Hanifa, Fitra Hasri Rosandi., S.Ant., M.PSDM.
}

${ }^{1 *}$ Fakultas Psikologi Universitas Teknologi Sumbawa

${ }^{2}$ Fakultas Psikologi Universitas Teknologi Sumbawa

\author{
*Corresponding Author email: 1/anahanifa98@gmail.com, 2fitra.hasri.rosandi@uts.ac.id
}

\begin{tabular}{ll}
\hline & Abstrak \\
\cline { 2 - 3 } Diterima : & Univeritas Teknologi Sumbawa tentunya memiliki tujuan yang harus dicapai. Kajian \\
Bulan Juni 2021 & mengenai psikologi rekayasa tata ruang kerja guna meningkatkan motivasi kerja tenaga \\
& kependidikan diharapkan dapat membuka pintu untuk mencapai tujuan tersebut. \\
& Penelitian ini dilakukan untuk mengetahui pengaruh psikologi rekayasa tata ruang kerja \\
Diterbitkan : & merhadap motivasi kerja tenaga kependidikan di Universitas Teknologi Sumbawa dengan \\
Bulan Juli 2021 & menggunakan jenis penelitian kuantitatif deskriptif. Pengambilan sampel penelitian ini \\
& kependidikan Universitas Teknologi Sumbawa. Data penelitian didapatkan dengan \\
Keyword: & menggunakan skala psikologi rekayasa tata ruang kerja dan skala motivasi kerja Hasil \\
Psikologi & penelitian menunjukan terdapat pengaruh psikologi rekayasa tata ruang kerja terhadap \\
Rekayasa, & motivasi kerja Tenaga Kependidikan Universitas Teknologi Sumbawa dengan nilai \\
Motivasi Kerja & signifikansi (Sig.) sebesar 0,035 (<0,05), didapatkan nilai R sebesar 0.334 dan nilai R \\
& Square sebesar 0,112. Dimana nilai R menunjukan nilai koefisien korelasi atau nilai \\
& hubungan psikologi rekayasa tata ruang kerja dengan motivasi kerja sebesar 0.334, \\
& berdasarkan tabel koefisien korelasi, nilai ini termasuk dalam kategori rendah, sehingga \\
& kontribusi pengaruh (R Square) psikologi rekayasa tata ruang kerja dalam meningkatkan \\
& motivasi kerja tenaga kependidikan hanya sebesar 11,2\%, sedangkan 88,8\% lainnya \\
& dipengaruhi oleh variabel lain yang tidak di teliti dalam penelitian ini.
\end{tabular}

\section{PENDAHULUAN}

Seiring dengan perkembangan zaman serta tingginya kebutuhan manusia. Perusahaan dituntut untuk tetap bertahan ditengah ketatnya persaingan. Berbagai cara dilakukan oleh perusahaan dalam upaya mempertahankan posisi terbaiknya dimata konsumen. Selain perlu memperhatikan kepuasan pengguna jasa, pengelolaan Sumber Daya Manusia yang baik juga dinilai sangat penting karena manusia merupakan pelaku utama sekaligus pengendali dinamis yang sangat dibutuhkan perusahaan. Dalam buku Manajemen Sumber Daya Manusia, Cascio (Nursalam, 2016 \& Fallis, 2013) menuturkan bahwa manusia adalah sumber daya yang sangat penting dalam bidang industri dan organisasi, oleh karena itu pengelolaan sumber daya mencakup penyediaan tenaga kerja yang bermutu, mempertahankan kualitas dan mengendalikan biaya ketenagakerjaan sangat diperlukan.

Setiap perusahaan tentu memiliki tujuan. Untuk mencapai tujuan perusahaan, banyak aspek yang harus diperhatikan salah satunya adalah motivasi kinerja karyawan. Perusahan harus mencari pemantik agar semangat para karayawan dalam menyelesaikan target-target perusahaan semakin tinggi. Muray (Yeni Febriani, 2020) menyebutkan bahwa motivasi kerja merupakan suatu dorongan yang memunculkan arah kerja.

Maka karyawan yang memiliki motivasi kerja tinggi akan bersemangat untuk menyelesaikan pekerjaan yang diberikan kepadanya, bersikap progresif, Serta akan berusaha mengerjakan perkerjaan dengan optimal. Sehingga akan menghasilkan karya terbaik untuk perusahaan. Sebaliknya jika motivasi kerja karyawan menurun. Pekerjaan akan menjadi beban yang berat dalam kehidupan sehari-harinya. mengerjakan tugas dengan tertekan, serta semangat yang menurun menyebabkan karyawan mengerjakan tugas terkesan seadanya. Hal ini tentu sangat merugikan perusahaan. Terlebih jika karyawan akhirnya mengabaikan pekerjaan, dan berujung pada pelanggaran disiplin, maka akan timbul masalahmasalah baru yang akan menghambat tercapainya tujuan perusahaan.

Dalam teori dua faktor yang dikemukakan oleh Herzberg (Munandar, 2014) menjelaskan bahwa fasilitas dan kondisi kerja dapat menjadi salah satu faktor motivasi kerja. Berbicara kondisi kerja tentunya berhubungan dengan Psikologi Rekayasa. Psikologi Rekayasa menurut Chapanis (Asih, 2009) memiliki tujuan untuk membantu membuat rancangan peralatan, tugas, tempat kerja, 
serta lingkungan kerja yang dapat menjadi kolaborasi yang tepat bagi kemampuan dan keterbatasan kerja karyawan. Diperjelas oleh Munandar (Munandar, 2014) bahwa tugas Psikologi Rekayasa adalah mengubah mesin-mesin dan alat yang digunakan manusia dalam pekerjaannya berdasarkan lingkungan tempatnya bekerja, agar lebih efisien.

Maka, Sebelum memutuskan fasilitas`apa yang akan diberikan kepada karyawan, penting untuk melakukan kajian mengenai psikologi rekayasa agar Fasilitas yang diberikan dapat tepat guna dan memberikan suntikan motivasi kepada karyawan. Karena ruang kerja yang tidak memadai akan menyebabkan rasa tidak nyaman bagi karyawan. Seperti ruangan kerja yang sempit namun di isi dengan banyak karyawan, akan menyebabkan terbatasnya ruang gerak antar karyawan sehingga karyawan tidak merasa nyaman berada didalam ruangan. Padahal bagi sebagian karyawan, ruangan kerja merupakan rumah kedua, karena aktifitas keseharian karyawan ada didalam ruang kerja.

Selain itu pencahayaan dalam ruangan juga perlu disesuaikan, karena saat ruangan terlalu gelap, ruangan akan terkesan buram dan sesak. Sebaliknya apabila ruangan terlalu terang, akan menjadi silau serta menimbulkan rasa tidak nyaman. Kebisingan dalam ruangan, serta suhu dalam ruangan juga tak kalah penting untuk diperhatikan demi kenyamanan dan maksimalisasi kinerja karyawan.

Penulis berinisiatif untuk meneliti pengaruh Psikologi Rekayasa Tata Ruang Kerja terhadap Motivasi Kerja Tenaga Kependidikan di Universitas Teknologi Sumbawa. dengan tujuan kenyamanan dan keamanan kerja karyawan. Dimana dengan kenyamanan dan rasa aman yang dirasakan, di harapkan akan timbul motivasi kerja yang tinggi serta keterikatan emosional yang baik antara tenaga kependidikan dengan universitas. .

Universitas Teknologi Sumbawa merupakan perusahaan yang bergerak dalam bidang pendidikan tinggi. Universitas ini memiliki letak geografis di dusun batu alang, desa leseng, kabupaten sumbawa besar, NTB, Indonesia. Dewasa ini, Universitas Teknologi Sumbawa sedang dalam masa pembangunan yang signifikan. sehingga dibutuhkan penelitian mengenai psikologi rekayasa tata ruang kerja agar pembangunan bisa tepat guna dan memberikan pengaruh besar bagi perkembangan Universitas terutama dapat meningkatkan motivasi kerja tenaga kependidikan agar tujuan Universitas dapat tercapai dengan optimal.

Selain itu, penelitian ini didukung oleh penelitian terdahulu. Seperti penelitian yang dilakukan oleh Revi Rezita pada tahun 2014, yang berjudul "PENGARUH LINGKUNGAN KERJA TERHADAP MOTIVASI KERJA KARYAWAN DI BANK JATIM CABANG UTAMA SURABAYA" Penelitian ini bertujuan untuk mendeskripsikan lingkungan kerja berpengaruh terhadap motivasi kerja karyawan di Bank Jatim Cabang Utama Surabaya, untuk mengetahui kondisi lingkungan kerja di Bank Jatim Cabang Utama Surabaya, dan untuk mengetahui tingkat motivasi kerja karyawan di Bank Jatim Cabang Utama Surabaya. Jenis penelitian ini adalah penelitian deskriptif pendekatan kuantitatif, dengan sampel 91 orang. hasil penelitian menunjukkan bahwa terdapat pengaruh yang signifikan antara variabel lingkungan kerja terhadap motivasi kerja karyawan. Tingkat motivasi kerja karyawan pada Bank Jatim Cabang Utama Surabaya adalah sangat baik. Hal ini terlihat dari nilai rata-rata skor motivasi kerja sebesar 4,25 yang berada pada kategori sangat setuju,sedangkan variabel lingkungan kerja memiliki nilai rata-rata skor sebesar 3,77 yang berada pada kategori setuju atau baik..

Disusul dengan penelitian yang dilakukan oleh Idris dan Halomoan pada tahun 2020 yang berjudul "PENGARUH TATA RUANG KANTOR TERHADAP KINERJA KARYAWAN PADA PT. SUCOFINDO (PERSERO) MEDAN" Berdasarkan hasil penelitian hubungan (korelasi) yang paling kuat indikatornya adalah $\mathrm{X} 1$ dengan $\mathrm{Y} 1$ yaitu $\mathrm{R}=$ 0,745 dan kontribusi yang disumbangkan sebesar $55,50 \%$. Dalam hasil uji regresi menunjukkan bahwa indikator yang paling dominan persamaan regresinya yaitu $\mathrm{X} 1$ terhadap $\mathrm{Y} 3$ nilainya adalah 0,962. Dan hasil Uji-t menunjukkan bahwa indikator yang paling dominan adalah $\mathrm{X} 1$ terhadap $\mathrm{Y} 1$ yaitu thitung $=3,406$ dimana tabel 2,16 maka thitung $3,406>$ ttabel 2,16 atau dengan kata lain $(\mathrm{Ha})$ diterima, artinya terdapat pengaruh yang signifikan antara X1 dengan Y1. Kemudian hasil Uji F menunjukkan bahwa indikator yang paling dominan adalah X1 terhadap Y1 yaitu Fhitung $=16,196$ ,dimana Ftabel $=4,67$ maka Ha diterima, artinya terdapat pengaruh yang signifikan antara X1 terhadap Y1.

Dari penelitian di atas, peneliti bermaksud menindak lanjuti penelitian dari sudut pandang psikologi rekayasa, dan berfokus pada pengaruhnya terhadap motivasi kerja karyawan. Penelitian mengenai psikologi rekayasa ini pertama dilakukan di Sumbawa, dengan harapan akan menumbuhkan semangat para peneliti untuk lebih mendalami phenomena psikologi kerekayasaan.

\section{LANDASAN TEORI}

\section{Psikologi Rekayasa Tata Ruang Kerja}

Menurut Chapanis (Asih, 2009) Psikologi rekayasa merupakan ilmu yang mempelajari interaksi Manusia, mesin, dan lingkungan yang dibutuhkan untuk menunjang pekerjaan sehingga dapat sesuai dengan kebutuhan dan keinginan tenaga kerja.

Chapanis juga menerangkan bahwa Ada beberapa istilah dalam penyebutan Psikologi Rekayasa. Antara lain Engineering Psychology, Human Factors Enginering, Biomechanics, 
Ergonomics, Psychotechnology, dan Applied Experimented Psychologi.

Munandar (Munandar, 2014) Meneruskan bahwa sebutan Human Factors Engineering merupakan sebutan yang digunakan di USA, sedangkan ditempat lain lebih dikenal dengan Ergonomics

Liker, Joseph dan Armstrong (Marras, 2006) menerangkan bahwa program ergonomic berfokus pada pengurangan cedera serta pengurangan konsekuensi kesalahan manusia atau biasa disebut "human factors".

Dalam kajian psikologi rekayasa, seorang psikolog harus mengetahui dan memahami konteks dunia nyata dalam pekerjaan serta relevansinya dengan tugas dan pengetahuan karyawan, yang selanjutnya akan menginspirasi design eskperimental (Aoki et al., 1984).

Dengan ini, dapat di artikan bahwa psikologi rekayasa merupakan ilmu yang mempelajari prilaku manusia yang berhubungan dengan mesin dan lingkungan fisik pekerjaan yang digunakan sebagai penunjang kerja. Sehingga peralatan yang tersedia bisa tepat guna, aman, dan nyaman digunakan oleh pekerja.

Dalam penyebutannya, psikologi rekayasa bisa juga disebut dengan ergonomic, human factors, biomechanic. Psychotechnology, dan applied experimented psychology. Semuanya memiliki tujuan yang sama yaitu memberikan rasa aman dan nyaman, serta mengurangi kemungkinan cedera dan kesalahan pada manusia (human factors).

Menurut (Munandar A. S., 2014) Psikologi rekayasa memandang pekerja sebagai suatu konstanta psikologis dan biologis yang mengandung banyak kecakapan dan keterbatasan yang ditentukan oleh pembawaan.

\section{Kondisi Kerja Fisik}

Kondisi fisik kerja adalah fasilitas fisik yang berkaitan dengan pekerjaan. Menurut (Munandar, 2014) Kondisi fisik kerja memperhatikan beberapa aspek, diantaranya :

a. Iluminasi (Penerangan).

Beberapa hal yang harus diperhatikan dalam iluminasi adalah intensitas cahaya, distribusi cahaya, dan sinar yang menyilaukan. Intensitas cahaya harus disesuaikan dengan pekerjaan, semakin tinggi tingkat pekerjaan yang membutuhkan kejelian mata, semakin tinggi pula intensitas cahaya yang dibutuhkan. Selanjutnya adalah distribusi cahaya. Distribusi cahaya didalam ruangan kerja harus merata sehingga penglihatan akan maksimal. Lebih tingginya kadar cahaya daripada daerah yang mengelilinginya bisa menyebabkan kelelahan pada mata.

Sinar yang menyilaukan juga harus dihindari karena dapat mengurangi efisiensi penglihatan. Sinar yang menyilaukan ini dapat disebabkan oleh sumber cahaya itu sendiri dan juga benda yang menyebabkan pantulan. Kajian dalam laboratorium menyebutkan bahwa silau menyebabkan peningkatan kesalahan dalam kerja rinci selama 20 menit.

b. Warna.

Pemberian warna pada ruangan dan tempat kerja memiliki makna. Warna-warna ini dapat digunakan sebagai :

1) Alat sandi

Biasanya menggunakan warna-warna yang konras, seperti merah, dan hijau, atau warnawarna lain yang terkesan kuat.

2) Relaksasi mata

Suyatno (Munandar, 2014) menyebutkan bahwa pentingnya mempertimbangkan keserasian antara warna dinding dengan perabotan dalam ruangan. Hal ini tentu penting agar penglihatan lebih relaks. Warna putih memantulkan cahaya lebih baik daripada warnawarna gelap.

3) Sebagai alat ilusi

Warna memiliki efek psikologis, penggunaan warna yang kurang tepat akan menyebabkan ruangan terlihat lebih sempit dan tertutup. Sebaliknya, dinding yang terang dan cerah akan memberikan kesan yang luas dan terbuka.

c. Bising.

Bising biasanya diartikan sebagai suara-suara yang mengganggu dan tidak di inginkan pendengarnya. Menurut McCormick (Munandar A. S., 2014) bising adalah suara-suara yang tidak mengandung informasi untuk penyelesaian tugas.

Satuan dasar untuk mengukur bising adalah decibel. Berikut merupakan table tingkat kebisingan yang ditentukan oleh menteri lingkungan hidup.

d. Musik Dalam Bekerja.

Musik dapat memberikan pengaruh yang baik bagi pekerjaan yang sederhana, rutin, dan monoton. Namun bagi pekerjaan yang lebih majemuk dan membutuhkan konsentrasi tinggi, musik akan berdampak negatif.

Menurut Suyatno (Munandar A. S., 2014) musik pengiring kerja harus dibarengi dengan beberapa pertimbangan sebagai berikut :

1. Musik dalam bekerja harus mencipyakan suasana akustik yang menghasilkan efek menenangkan.

2. Musik akan bernila pada pekerja tangan dan pekerjaan yang memerlukan sedikit kegiatan mental

3. Musik tidak akan bernilai tinggi jika ada suara atau bunyi lain yang cukup keras.

4. Musik bernada meriah diperdengarakan secara singkat pada awal hari, pertengahan kerja, dan untuk memperbaiki gairah. 
5. Tempo musik tidak terlalu lambat dan tidak terlalu cepat, karena irama yang lambat akan menyebabkan pekerja mengantuk, sedangkan irama yang terlalu ceoat akan mengganggu konsentrasi.

\section{Motivasi Kerja}

Pengertian motivasi kerja menurut Sagian (Suwati, 2013) dimana motivasi kerja dikatakan sebagai daya pendorong yang menyebabkan seorang karyawan rela untuk bekerja sepenuh hati, menuangkan keahliannya, serta tanggung jawab pekerjaan yang diberikan kepadanya, dalam rangka mencapai tujuan dan sasaran yang di inginkan. Didukung oleh pengertian motivasi kerja menurut Manullang (Rezita, 2014) mengemukakan bahwa motivasi kerja merupakan sesuatu yang menimbulkan semangat atau dorongan kerja.

Dengan demikian, penulis mendapatkan pengertian motivasi kerja adalah suatu dorongan baik dari dalam maupun dari luar diri seseorang untuk bergerak melakukan suatu pekerjaan dengan tujuan tertentu. Motivasi kerja juga dapat dikatakan sebagai suatu dorongan yang ada dalam jiwa manusia untuk menimbulkan tindakan dan kekuatan demi capaian-capaian yang di inginkan dalam pekerjaan. Maka jika motivasi kerja melemah, otomatis gairah terhadap pekerjaan akan turun. Antusias mengerjakan tugas-tugas pekerjaan akan melemah. Tentunya akan berdampak pada hasil kerja karyawan dan terhambatnya proses pencapaian tujuan perusahaan. Untuk meningkatkan motivasi karyawan, maka perusahaan harus memperhatikan beberapa faktor yang dapat mempengaruhi motivasi kerja.

\section{Faktor Motivasi Kerja}

Herzberg (Waluyo, 2013) mengemukakan teori hygiene-motivasi atau dikenal dengan teori dua faktor. Ia mengemukakan bahwa terdapat dua faktor yang mempengaruhi pekerjaan mencakup isi dari pekerjaan itu sendiri (faktor intrinsik), dan faktor lain yang mempengaruhi motivasi kerja (faktor ekstrinsik). Faktor intrinsik diantaranya adalah :

1) Tanggung jawab (Responsibility)

2) Kemajuan (Advanced)

3) Pekerjaan itu sendiri

4) Capaian (achievement)

5) Pengakuan (Recognition)

Sedangkan faktor ekstrinsik meliputi :

1) Administrasi dan kebijakan

2) Penyediaan Fasilitas

3) Gaji

4) Hubungan interpersonal

5) Kondisi kerja

\section{Tenaga Kependidikan}

Tenaga kependidikan menurut Yahya (Ananda, 2018) merupakan pekerjaan yang berkaitan dengan proses penyelenggaraan pendidikan yang dapat menghasilkan dan dilakukan dengan kemahiran, keterampilan, dan kecakapan tertentu serta didasarkan pada norma yang berlaku.

Tugas tenaga kependidikan diatur dalam UndangUndang Republik Indonesia nomor 20 Tahun 2003 (RI, 2003) tentang Sistem Pendidikan Nasional bab I pasal 1 menyebutkan bahwa tenaga kependidikan adalah anggota masyarakat yang mengabdikan diri dengan kriteria dan standar tertentu dan diangkat untuk menunjang penyelenggaraan proses pendidikan pada satuan pendidikan seperti pendidik, kepala sekolah, pengawas, laboran, pustakawan, peneliti, dan tenaga teknis administrasi penyelenggaraan pendidikan.

Tugas pokok tenaga kependidikan juga dijelaskan dalam Undang-Undang Republik Indonesia nomor 10 Tahun 2003 tentang Sistem Pendidikan Nasional bab XI pasal 39 ayat 1 menjelaskan bahwa tugas pokok tenaga kependidikan adalah melaksanakan administrasi, pengelolaan, pengembangan, pengawasan, dan pelayanan teknis untuk menunjang proses pendidikan pada satuan pendidikan.

Hak dan kewajiban tenaga kependidikan juga dijelaskan dalam Undang-Undang Republik Indonesia nomor 20 Tahun 2003 tentang Sistem Pendidikan Nasional diantaranya :

1. Memperoleh penghasilan dan jaminan kesejahteraan sosial yang pantas dan memadai.

2. Memperoleh penghasilan sesuai dengan tugas dan prestasi kerja.

3. Memperoleh pembinaan karir sesuai dengan tuntunan pengembangan kualitas.

4. Memperoleh perlindungan hukum dalam pelaksanaan tugas dan ha katas hasil kekayaan interlektual.

5. Memperoleh kesempatan untuk menggunakan sarana, prasarana, dan fasilitas pendidikan untuk menunjang kelancaran pelaksanaan tugas.

Kewajiban tenaga kependidikan meliputi :

1. Menciptakan suasana pendidikan yang bermakna, menyenangkan, kreatif, dinamis, dan dialogis.

2. Berkomitmen secara professional untuk meningkatan mutu pendidikan.

\section{Kerangka Penelitian}

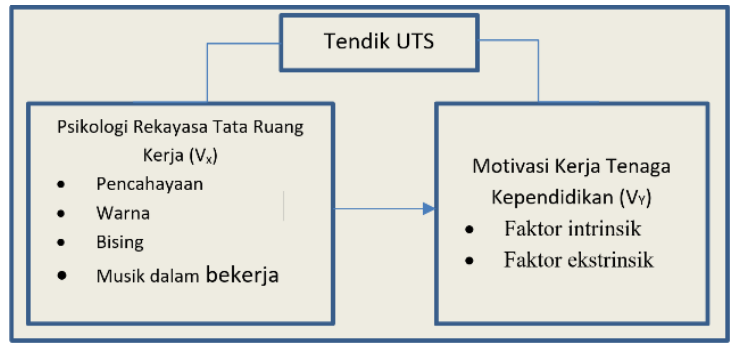


Dalam penelitian ini, Tenaga Kependidikan Unversitas Teknologi Sumbawa sebagai Subjek penelitian, Psikologi Rekayasa Tata Ruang sebagai variabel bebas (X) dan Motivasi Kerja sebagai variabel terikat (Y). Dari masingmasing variabel terdapat beberapa aspek sebagai landasan penyusunan skala. Dimana Psikologi Rekayasa Tata Ruang memiliki lima aspek diantaranya adalah, Pencahayaan, warna, kebisingan, dan musik dalam bekerja. Sedangkan Motivasi Kerja memiliki tiga dua aspek diantaranya adalah faktor intrinsik dan faktor ekstrinsik.

\section{METODE PENELITIAN}

\section{Jenis Penelitian}

Penelitian ini menggunakan metode penelitian kuantitatif deskriptif dengan menyebar angket, dan dokumentasi. Penelitian kuantitatif menurut (Sugiyono, 2008) adalah metode penelitian ilmiah yang memenuhi kaidah-kaidah ilmiah yaitu konkret/empiris, obyektif, terukur, rasional, dan sistematis.

Jenis penelitian kuantitatif deskriptif ini digunakan untuk mengetahui pengaruh Psikologi rekayasa tata ruang kerja terhadap motivasi kerja Tenaga Kependidikan Universitas Teknologi Sumbawa.

\section{Variabel Penelitian}

Variabel penelitian menurut (Sugiyono, 2008) merupakan suatu atribut, sifat, atau nilai dari orang, kegiatan, atau obyek yang memiliki variasi tertentu yang ditetapkan oleh peneliti untuk ditarik kesimpulannya.

Dalam penelitian ini, peneliti menggunakan Psikologi rekayasa bentuk dan ruang sebagai variabel bebas (X) dan Motivasi kerja sebagai variabel terikat $(\mathrm{Y})$

\section{Populasi dan Sampel}

Populasi dalam penelitian ini adalah seluruh tenaga Kependidikan administratif (tendik nonteknis) Universitas Teknologi Sumbawa yang berjumlah 67 orang.

Penelitian ini menggunakan teknik sampling Probability Sampling dengan jenis teknik Simple Random Sampling teknik ini dipilih karena populasi yang diteliti bersifat homogeny. dikatakan simple karena teknik penentuan sampel dalam penelitian ini sangat sederhana, tanpa memperhatikan strata yang ada dalam populasi itu.

Sampel di tentukan dengan rumus Slovin dengan tingkat kesalahan $10 \%$ dengan rumus

$$
\begin{aligned}
& n=\frac{N}{1+N(e)^{2}} \\
& \mathrm{n}=\text { Besaran Sampel } \\
& \mathrm{N}=\text { Besaran Populasi } \\
& \mathrm{E}=\text { Nilai Kritis (batas ketelitian) yang diinginkan } \\
& 10 \%
\end{aligned}
$$

$$
n=\frac{67}{1+67(0,1)^{2}}=\frac{67}{1+67(0,01)}=
$$$$
40,11=40
$$

Berdasarkan perhitungan diatas, maka didapatkan jumlah sampel sebanyak 40 sampel.

\section{Instrumen Penelitian}

Dalam penelitian ini, peneliti membuat secara pribadi skala penelitian yang digunakan. Dalam Psikologi rekayasa tata ruangan kerja terdapat empat unsur yaitu Pencahayaan/iluminasi, Warna, Bising, dan Musik dalam bekerja menghasilkan 18 Item.

Sedangkan untuk skala motivasi kerja terdapat dua faktor motivasi kerja yaitu, Faktor intrinsic dan factor ekstrisik yang menghasilkan 30 Item. dalam penelitian ini terdiri dari pernyataan favorable (pernyataan mendukung) dan unfavorable (pernyataan tidak mendukung) skala dalam penelitian ini menggunakan skala likert dimana skala ini berisi pertanyaan yang sistematis untuk menunjukan sikap responden terhadap pernyataan yang diberikan.

1. Skala Psikologi Rekayasa Bentuk dan Tata Ruang Skala psikologi rekayasa bentuk dan tata ruang disusun secara mandiri oleh peneliti dengan menggunakan teori kondisi kerja fisik yang dikemukakan oleh Munandar. Terdapat empat unsur kondisi kerja fisik yaitu Pencahayaan/iluminasi, warna, bising, dan music dalam bekerja. Empat unsur ini menghasilkan 18 Item yang selanjutnya setelah di uji coba menghasilkan 14 item yang dinyatakan valid dan 4 item yang dinyatakan tidak valid atau gugur.

2. Skala Motivasi Kerja

Skala Motivasi Kerja disusun secara mandiri oleh peneliti dengan menggunakan teori dua faktor motivasi kerja yang dikemukakan oleh Herzberg yaitu faktor intrinsik dan faktor ekstrinsik. Tiga unsur ini menghasilkan 30 Item yang selanjutnya setelah dilakukan uji coba menghasilkan 22 Item yang dinyatakan valid, dan 8 item yang dinyatakan tidak valid atau gugur.

\section{Teknik Pengumpulan Data}

1. Skala

Skala menurut (Usman Rianse., 2020) merupakan kesepakatan yang digunakan peneliti sebagai acuan guna menentukan panjang pendeknya interval dalam suatu alat ukur, serta skala dapat mengurutkan responden kedalam urutan ordinal dengan tepat. Dalam penelitian ini, peneliti menggunakan skala likert menurut (Sugiyono, 2008) merupakan skala yang digunakan untuk mengukur sikap, pendapat, dan persepsi seseorang atau kelompok tentang suatu fenomena. Kategori dalam skala yang disusun peneliti memiliki urutan mulai dari "Sangat setuju, setuju, tidak setuju, dan sangat tidak setuju" 


\section{Dokumentasi}

Dokumentasi merupakan dokumendokumen yang dikumpulkan peneliti untuk menunjang penelitian. Adapun dokumen yang digunakan dalam penelitian ini adalah jumlah data tenaga kependidikan.

\section{Teknik Analisis Data}

1. Uji Validitas

Validitas menurut (Azwar, 2015) berarti sejauh mana akurasi suatu alat ukur dalam melaksanakan pengukurannya. Akurat berarti tepat dan cermatsehingga alat ukur akan menghasilkan data yang akurat. Alat ukur yang kurang valid akan menunjukan angka validitas yang rendah. Untuk menguji validitas, peneliti menggunakan bantuan SPSS (Statistical Product and Service Solution) versi 16 for windows.

a. Uji Validitas Psikologi Rekayasa Tata Ruang Kerja.

Suatu Item dinyatakan valid jika nilai $r_{\text {hitung }}>r_{\text {tabel }}$ (menurut siapa). Dalam uji validitas instrumen terdapat 30 responden. Dengan derajat kebebasan $(\mathrm{df}=\mathrm{N}-2)$ untuk $\alpha=0,05$ di dapatkan nilai $\mathrm{r}_{\text {tabel }}$ sebesar 0,361. Berdasarkan analisis data, diketahui bahwa dari 18 item dalam skala Psikologi Rekayasa Tata Ruang Kerja didapatkan 14 item yang valid yaitu pada nomor 1, 2, 3, 4, 5, 7, 8, 10, $12,14,15,16,17,18$. Sedangkan 4 item lainnya yaitu $6,9,11,13$, dinyatakan tidak valid atau gugur.

\section{b. Uji Validitas Motivasi Kerja}

Suatu Item dinyatakan valid jika nilai $r_{\text {hitung }}>r_{\text {tabel }}$ (menurut siapa). Dalam uji validitas instrumen terdapat 30 responden. Dengan derajat kebebasan $(\mathrm{df}=\mathrm{N}-2)$ untuk $\alpha=0,05$ di dapatkan nilai $\mathrm{r}_{\text {tabel }}$ sebesar 0,361 .

Berdasarkan analisis data, diketahui bahwa dari 30 item dalam skala Motivasi Kerja didapatkan 22 item yang valid yaitu pada nomor $3,4,5,6,7$, $8,10,11,12,14,16,18,19,20,21,22,23,24,25$, 27,30 . Sedangkan 8 item lainnya yaitu 1, 2, 13, 15, $17,26,28,29$,dinyatakan tidak valid atau gugur.

\section{Uji Reliabilitas}

Reliabel menurut (Azwar, 2015) adalah sejauhmana hasil dalam proses pengukuran dapat dipercaya. Hasil pengukuran dapat dipercaya apabila hasil pengukuran relatif sama setelah dilakukan beberapa kali. Untuk menguji reliabilitas, peneliti menggunakan bantuan SPSS (Statistical Product and Service Solution). Machali (2017), menyatakan bahwa nilai koefisien cronbach's alpha $\geq 0,7$. Maka instrument dapat dikatakan reliable.

a. Uji Reliabilitas Skala Psikologi Rekayasa Tata Ruang Kerja
Berdasarkan analisis yang telah dilakukan, maka diketahui bahwa nilai cronbach's alpha adalah 0,712. Hal ini menunjukan bahwa nilai cronbach's alpha $\geq 0,7$ menandakan bahwa instrument tersebut dapat dinyatakan reliabel.

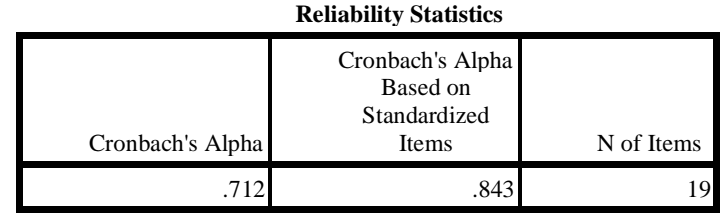

Tabel 1. Reliabilitas Psikologi Rekayasa Tata Ruang Kerja

\section{b. Uji Reliabilitas Skala Motivasi Kerja}

Berdasarkan analisis yang telah dilakukan, maka diketahui bahwa nilai cronbach's alpha adalah 0,713. Hal ini menunjukan bahwa nilai cronbach's alpha $\geq 0,7$ menandakan bahwa instrument tersebut dapat dinyatakan reliabel.

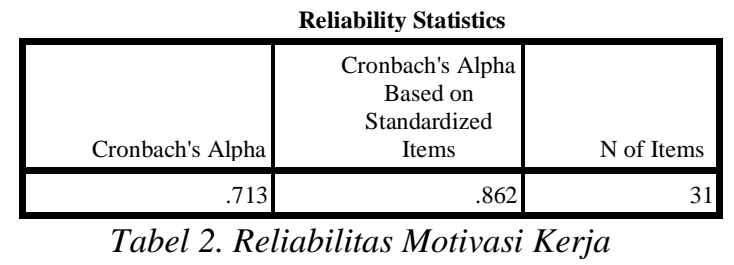

\section{Kriteria Pembanding}

1. Kategorisasi Tingkat Psikologi Rekayasa Tata Ruang Kerja dan Motivasi Kerja

Norma atau kriteria pembanding yang digunakan oleh peneliti terbagi menjadi empat bagian yaitu sangat tinggi, tinggi, rendah, dan sangat rendah.

\begin{tabular}{|c|c|}
\hline Interval Skor & Kategori \\
\hline $\mathrm{M}+1,5 \mathrm{SD}<\mathrm{X}$ & Sangat Tinggi \\
\hline $\begin{array}{c}\mathrm{M}+0,5 \mathrm{SD}<\mathrm{X} \leq \mathrm{M} \\
+1,5 \mathrm{SD}\end{array}$ & Tinggi \\
\hline $\begin{array}{c}\mathrm{M}-0,5 \mathrm{SD}<\mathrm{X} \leq \mathrm{M}+ \\
0,5 \mathrm{SD}\end{array}$ & Sedang \\
\hline $\begin{array}{c}\mathrm{M}-1,5 \mathrm{SD}<\mathrm{X} \leq \mathrm{M}- \\
0,5 \mathrm{SD}\end{array}$ & Rendah \\
\hline $\mathrm{X} \leq \mathrm{M}-1,5 \mathrm{SD}$ & Sangat Rendah \\
\hline
\end{tabular}

Tabel 3. Kriteria pembanding Kategorisasi Tingkat

2. Kategorisasi Rerata Aspek

Norma atau kriteria pembanding yang digunakan peneliti dalam mengkategorikan rata-rata nilai setiap aspek dibagi menjadi 3 (tiga) kategori yaitu, tinggi, cukup, dan rendah.] 


\begin{tabular}{|c|c|}
\hline Interval Skor & Kategori \\
\hline $1-2$ & Rendah \\
\hline $2-3$ & Cukup \\
\hline $3-4$ & Tinggi \\
\hline
\end{tabular}

Tabel 4. Kriteria Pembanding Rerata Aspek

\section{Kategorisasi Interpretasi Koefisien Korelasi}

Norma kategorisasi Koefien Korelasi yang digunakan peneliti dalam mengkategorikan nilai koefisien korelasi terbagi menjadi lima kategori, yaitu, sangat rendah, rendah, sedang, kuat, dan sangat kuat.

\begin{tabular}{|l|l|}
\hline \multicolumn{1}{|c|}{ Interval Koefisien } & Tingkat Hubungan \\
\hline $0,00-0,199$ & Sangat Rendah \\
\hline $0,20-0,399$ & Rendah \\
\hline $0,40-0,599$ & Sedang \\
\hline $0,60-0,799$ & Kuat \\
\hline $0.80-1,000$ & Sangat Kuat \\
\hline
\end{tabular}

Tabel 5. Kategorisasi Interpretasi Koefisien Korelasi

\section{Uji Hipotesis}

Uji Hipotesis yang digunakann dalam penelitian ini adalah uji regresi linier sederhana. Menurut Machali (2017). Menyatakan bahwa regresi linier sederhana digunakan untuk mengukur pengaruh satu variabel independen $(\mathrm{X})$ terhadap variabel dependen $(\mathrm{Y})$.

Regresi linier sederhana digunakan peneliti untuk mengetahui ada atau tidaknya pengaruh Psikologi rekayasa tata ruang kerja terhadap motivasi kerja tenaga kependidikan di Universitas Teknologi Sumbawa. Adapun standar signifikansi (Sig.) sebesar <0,05 dinyatakan berpengaruh.

\section{HASIL DAN PEMBAHASAN}

Setiap perusahaan pasti memiliki tujuan yang harus dicapai. Dalam prosesnya banyak aspek yang harus diperhatikan, salah satunya adalah motivasi kerja karyawan. Muray (Yeni Febriani, 2020) menyebutkan bahwa motivasi kerja merupakan suatu dorongan yang memunculkan arah kerja. Maka karyawan yang memiliki motivasi kerja tinggi akan bersemangat untuk menyelesaikan pekerjaan yang diberikan kepadanya, bersikap progresif, Serta akan berusaha mengerjakan perkerjaan dengan optimal. Sehingga akan menghasilkan karya terbaik untuk perusahaan. Sebaliknya jika motivasi kerja karyawan menurun. Pekerjaan akan menjadi beban yang berat dalam kehidupan sehari-harinya. mengerjakan tugas dengan tertekan, serta semangat yang menurun menyebabkan karyawan mengerjakan tugas terkesan seadanya. Hal ini tentu sangat merugikan perusahaan. Terlebih jika karyawan akhirnya mangkir dari pekerjaan, dan berujung pada pelanggaran disiplin, maka akan timbul masalah-masalah baru yang akan menghambat tercapainya tujuan perusahaan.

Dalam teori dua faktor yang dikemukakan oleh Herzberg (Munandar, 2014) menjelaskan bahwa fasilitas dan kondisi kerja dapat menjadi salah satu faktor pemicu motivasi kerja. Berbicara kondisi kerja tentunya berhubungan dengan Psikologi Rekayasa. Psikologi Rekayasa menurut Chapanis (Asih, 2009) memiliki tujuan untuk membantu membuat rancangan peralatan, tugas, tempat kerja, serta lingkungan kerja yang dapat menjadi kolaborasi yang tepat bagi kemampuan dan keterbatasan kerja karyawan. Diperjelas oleh Munandar (Munandar, 2014) bahwa tugas Psikologi Rekayasa adalah mengubah mesin-mesin dan alat yang digunakan manusia dalam pekerjaannya berdasarkan lingkungan tempatnya bekerja, agar lebih efisien. Psikologi Kerekayasaan menurut (Waluyo, 2013) merupakan penerapan ilmu psikologi yang berkaitan dengan interaksi antara manusia dengan mesin atau alat penunjang kerja bertujuan untuk meminimalisir kesalahan dalam bekerja (human error).

Maka, Sebelum memutuskan fasilitas' apa yang akan diberikan kepada karyawan, penting untuk melakukan kajian mengenai psikologi rekayasa agar Fasilitas yang diberikan dapat tepat guna dan memberikan suntikan motivasi kepada karyawan. Karena ruang kerja yang tidak memadai akan menyebabkan rasa tidak nyaman bagi karyawan. Seperti ruangan kerja yang sempit namun di isi dengan banyak karyawan, akan menyebabkan terbatasnya ruang gerak antar karyawan sehingga karyawan tidak merasa nyaman berada didalam ruangan. Padahal bagi sebagian karyawan, ruangan kerja merupakan rumah kedua, karena aktifitas keseharian karyawan ada didalam ruang kerja. Selain itu pencahayaan dalam ruangan juga perlu disesuaikan, karena saat ruangan terlalu gelap, ruangan akan terkesan buram dan sesak. Sebaliknya apabila ruangan terlalu terang, akan menjadi silau serta menimbulkan rasa tidak nyaman. Kebisingan dalam ruangan, serta suhu dalam ruangan juga tak kalah penting untuk diperhatikan demi kenyamanan dan maksimalisasi kinerja karyawan. Bahasan Psikologi Rekayasa pada penelitian ini berfokus pada pengaruh psikologi rekayasa tata ruang kerja terhadap motivasi kerja Tenaga Kependidikan di Universitas Teknologi Sumbawa. 
Universitas Teknologi Sumbawa adalah sebuah perusahaan yang bergerak dibidang pendidikan, sehingga karyawan yang turut menggerakan roda perusahaan disebut dengan tenaga kependidikan. Tenaga kependidikan menurut Yahya (Ananda, 2018) merupakan pekerjaan yang berkaitan dengan proses penyelenggaraan pendidikan yang dapat menghasilkan dan dilakukan dengan kemahiran, keterampilan, dan kecakapan tertentu serta didasarkan pada norma yang berlaku.

Berdasarkan hasil penelitian menggunakan analisis regresi linier sederhana, diketahuiPsikologi rekayasa tata ruang kerja memiliki pengaruh terhadap motivasi kerja tenaga kependidikan karena memiliki nilai signifikansi (Sig.) sebesar 0,035 (< 0,005). Yang berarti bahwa apabila kualitas penataan ruang kerja di Universitas Teknologi Sumbawa meningkat, maka akan meningkat pula motivasi tenaga kependidikannya. Berdasarkan hasil analisis data, diketahui $\mathrm{R}$ sebesar 0.334 dan nilai $\mathrm{R}$ Square sebesar 0,112. Dimana nilai $\mathrm{R}$ menunjukan nilai koefisien korelasi atau nilai hubungan Psikologi rekayassa tata ruang kerja dengan motivasi kerja sebesar 0.334, Berdasarkan tabel koefisien korelasi, nilai ini termasuk dalam kategori rendah, sehingga kontribusi pengaruh Psikologi rekayasa tata ruang kerja dalam meningkatkan motivasi kerja tenaga kependidikan hanya sebesar $11,2 \%$, sedangkan $88,8 \%$ lainnya dipengaruhi oleh variabel lain yang tidak di teliti dalam penelitian ini.

Dalam penelitian ini, untuk skala psikologi rekayasa tata ruang kerja peneliti menggunakan teori kondisi kerja fisik yang dikemukakan oleh (Munandar, 2014) dengan empat aspek kondisi kerja fisik yaitu Pencahayaan/iluminasi, Warna, Bising, dan Musik dalam bekerja. Berdasarkan hasil anaisis data, aspek pencahayaan berada pada kategori tinggi dengan nilai rerata aspek sebesar 3,13. Aspek Warna berada pada kategori Tinggi denga nilai rerata aspek 3,13. Aspek kebisingan berada pada kategori cukup dengan nilai rerata aspek sebesar 2,84, dan aspek music berada pada kategori cukup degan nilai rerata aspek sebesar 2.81. maka nilai rerata aspek ppada skala psikologi rekayasa tata ruang kerja sebesar 2.98 dengan kategori cukup.

Skala Motivasi kerja dalam penelitian ini menggunakan teori dua faktor yang dikemukakan oleh Herzberg. Dimana terdapat dua aspek yaitu faktor intrinsik dan faktor ekstrinsik. Keduanya berada pada kategori tinggi dengan faktor intrinsik memiliki nilai rerata aspek sebesar 3,38, dan faktor ekstrinsik memiliki nilai rerata aspek sebesar 3,32. Dengan keseluruhan jumlah total rerata aspek untuk skala motivasi kerja sebesar 3,31 dengan kategori tinggi.

\section{PENUTUP}

\section{Kesimpulan}

Berdasarkan hasil penelitian yang dilakukan di Universitas Teknologi Sumbawa, dapat disimpulkan bahwa terdapat pengaruh psikologi rekayasa tata ruang kerja terhadap motivasi kerja Tenaga Kependidikan Universitas Teknologi Sumbawa dengan nilai signifikansi (Sig.) sebesar $0,035 \quad(<0,05)$, menunjukan bahwa hipotesis alternative (Ha) diterima. Hasil tersebut menunjukan bahwa semakin baik tata ruang kerja di universitas teknologi Sumbawa, maka semakin tinggi pula motivasi kerja tenaga kependidikan. Dari hasil output SPSS versi 16 for windows, diketahui nilai $\mathrm{R}$ sebesar 0.334 dan nilai $\mathrm{R}$ Square sebesar 0,112 . Dimana nilai $R$ menunjukan nilai koefisien korelasi atau nilai hubungan Psikologi rekayassa tata ruang kerja dengan motivasi kerja sebesar 0.334, Berdasarkan tabel koefisien korelasi, nilai ini termasuk dalam kategori rendah, sehingga kontribusi pengaruh (R Square) Psikologi rekayasa tata ruang kerja dalam meningkatkan motivasi kerja tenaga kependidikan hanya sebesar 11,2\%, sedangkan $88,8 \%$ lainnya dipengaruhi oleh variabel lain yang tidak di teliti dalam penelitian ini.

\section{REFERENSI}

Ananda, R. (2018). Profesi Pendidik dan Tenaga Kependidikan.

http://library1.nida.ac.th/termpaper6/sd/2554/ 19755.pdf

Aoki, M., Ohkubo, T., Horie, Y., \& Saito, S. (1984). Vdt and Human Performance.

Asih. (2009). 20171115110701-ErgonomikaDalam-Kehidupan-Sehari-Hari.pdf (p. 96). Semarang University Press.

Asnar, Z. H. (2013). pengaruh tata ruang kantor terhadap produktivitas kerja pegawai di pusat kajian dan pendidikan dan pelatihan aparatur III LAN Samarinda. EJurnal Ilmu Pemerintahan, 1(4), 1488-1500.

Faridah. (2009). Analisis Faktor Faktor yang Berpengaruh Terhadap Motivasi Kerja Petugas Pelaksana Manajemen Terpadu Balita Sakit (MTBS) di Puskesmas kota Surabaya.

Harefa, D. (2020). Pengaruh Antara Motivasi Kerja Guru IPA dan Displin terhadap Prestasi Kerja. Jurnal Ilmu Pendidikan Nonformal, 06(03), 225-240.

Hitt; Miller; Colella. (2006). Organizational Behavior (Third edit). John Wiley \& Sons, Inc.

Kartika, E. W., \& Kaihatu, T. S. (2010). Analisis Pengaruh Motivasi Kerja Terhadap Kepuasan Kerja (Studi Kasus pada Karyawan Restoran di Pakuwon Food Festival Surabaya). Jurnal Manajemen Dan Kewirausahaan (Journal of Management and Entrepreneurship), 12(1), 100-112. 
https://doi.org/10.9744/jmk.12.1.pp.100-112

Leonando Agsta, \& Sutanto, E. M. (2013). Pengaruh Pelatihan Dan Motivasi Kerja Terhadap Kinerja Karyawan Cv Haragon Surabaya. Pengaruh Pelatihan Dan Motivasi Terhadap Kinerja Karyawan CV Haragon Surabaya, 1(3), 1 .

Marras, W. S. (2006). Fundamentals and Assessment Tools for Occupational Ergonomics. In Fundamentals and Assessment Tools for Occupational Ergonomics. https://doi.org/10.1201/9781420003635

Nursalam, 2016, metode penelitian, \& Fallis, A. . (2013). 済無No Title No Title. Journal of Chemical Information and Modeling, 53(9), 1689-1699.

Rezita, R. (2014). Pengaruh Lingkungan Kerja Terhadap Motivasi Kerja Karyawan di Bank Jatim Cabang Utama Surabaya Pengaruh Lingkungan Kerja Terhadap Motivasi Kerja Karyawan di Bank Jatim Cabang Utama Surabaya. Jurnal Pendidikan Administrasi Perkantoran, 2(2), 1-15.

RI, U. (2003). Undang-Undang Republik Indonesia Nomor 20 Tahun 2003.

Suwati, Y. (2013). Pengaruh Kompensasi Dan Motivasi Kerja Terhadap Kinerja Karyawan Pada Pt. Tunas Hijau Samarinda. EJournal Ilmu Administrasi Bisnis, 1(1), 41-55.

Yakup, Y. (2017). Pengaruh Keterlibatan Kerja, Budaya Organisasi dan Motivasi Kerja terhadap Kepuasan Kerja Pegawai. Perisai: Islamic Banking and Finance Journal, 1(3), 273.https://doi.org/10.21070/perisai.v1i3.112
Azwar, S. (2015). Reliabilitas dan Validitas. Yogyakarta: Pustaka Pelajar.

Munandar, A. S. (2014). Psikologi Industri dan Organisasi. Jakarta, Jakarta, Indonesia: UI Press.

Munandar, A. S. (2014). Psikologi Industri Dan Organisasi. Jakarta, Jakarta: UI-PRESS.

Sugiyono. (2008). Metode Penelitian Kuantitatif Kualitatif Dan $R \& D$. Bandung: ALVABETA, cv.

Usman Rianse., A. (2020). Metodologi Penelitian Sosial dan Ekonomi Teori dan Aplikasi. Bandung: ALFABETA.

Waluyo, M. (2013). Psikologi Industri. Jakarta: Akademia.

Yeni Febriani. (t.thn.).

Yeni Febriani, E. B. (2020). Hubungan gaya kepemimpinan dengan motivasi kerja pada HMJ Psikologi Universitas Negeri Surabaya. Prosiding Jurnal Psikologi. 